
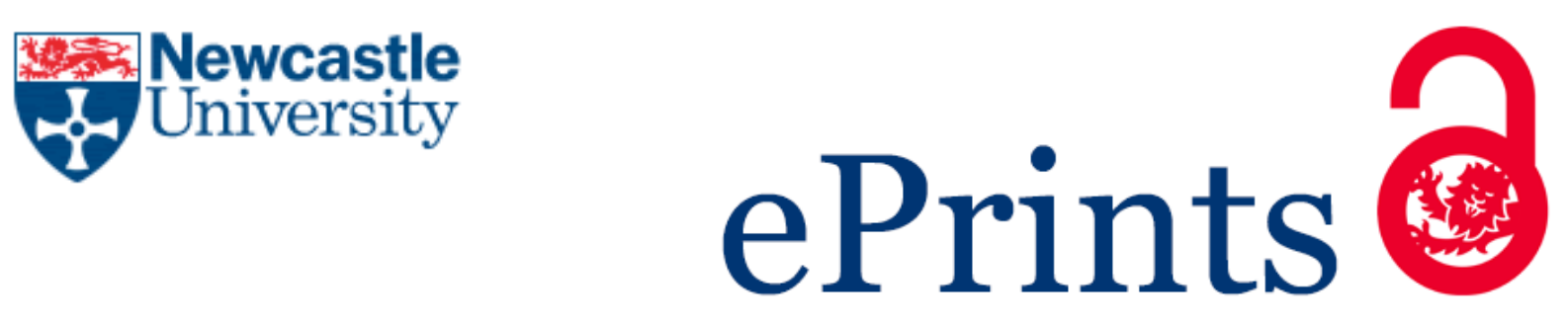

\author{
Dawson RJ, Walsh CL, Purnell P, Rogers CDF. \\ Briefing: Infrastructure business models, valuation and innovation for local \\ delivery. \\ Infrastructure Asset Management 2014, 1(3), 66-67.
}

This is the authors' manuscript of an article published in its final form by ICE Publishing, 2014.

Journal homepage:

http://www.icevirtuallibrary.com/content/serial/iasma

Link to published article:

http://dx.doi.org/10.1680/iasma.14.00027

Date deposited:

$21 / 01 / 2015$

Embargo release date:

01 July 2015 


\section{Infrastructure Business Models, Valuation and Innovation for Local Delivery}

The UK's Engineering \& Physical Sciences Research Council and the Economic \& Social Research Council have launched a $£ 3.5 \mathrm{~m}, 4$ year research programme to develop innovative business models for delivering infrastructure. Richard Dawson, Claire Walsh, Phil Purnell and Chris Rogers introduce iBUILD (Infrastructure BUsiness models, valuation and Innovation for Local Delivery).

A growing population, extreme weather, decarbonisation, a proliferation of new technologies and integration of new with ageing existing systems are just some of the pressures on modern infrastructure systems. Yet, investment has not kept up with the pace of change. This is further complicated by fragmented, often reactive, regulation and governance arrangements. The UK Treasury Select Committee noted that existing infrastructure business models provide poor valuei but few alternatives are available - a point picked up by Infrastructure UK ${ }^{\text {ii }}$ who called for research Centres to be founded to address this. The iBUILD Centre will address this through development of a suite of alternative infrastructure business models, ranging from reforms to existing approaches to radical new models, that enable more effective delivery of local infrastructures.

\section{A systems view}

Some of the limitations of existing business models stem from a narrow definition of infrastructure that typically focuses on the physical artefacts. Yet, these rely on a series of processes (e.g. design, finance, operation) that enable the movement of resources (data, energy, people etc.) to provide the services that maintain (and ideally enhance) security, health, economic growth and quality of life for users and society at large. A systems approach helps identify the multiple ways these aspects are intertwined, thereby illuminating an extensive set of possible mechanisms for capturing economic as well as social and environmental value. Physical dependencies between infrastructure systems are increasingly recognised; however, socio-economic dependencies, arising from investment cycles, funding and finance practises, valuation techniques, policy, regulation of pricing or major external shocks such as a 'credit crunch', are less well understood.

\section{A focus on local infrastructure}

National infrastructure plans and projects provide strategic context, but poor local infrastructure inhibits growth and other activitiesiii. Moreover balancing growth across regions and scales is crucial to the success of a national economy ${ }^{\text {iv }}$. The UK's localism agenda is encouraging new approaches to local infrastructure provision and devolving funding powers. 'City Deals ${ }^{\prime v}$ are using mechanisms such as Tax Increment Financing to fund local infrastructure, but these approaches have had mixed results in the USA, with some cities filing for bankruptcy ${ }^{\mathrm{vi}}$, and remain unproven in the UK over the long term. In keeping with a systems approach, local scale infrastructure has the potential to be accessible to far more agents (e.g. SMEs, community groups) as upfront investment is lower, enabling innovation, entrepreneurialism and novel delivery models. Furthermore, as many systems decentralise, the role of community or household measures (e.g. small-scale generation or demand management) and associated agents will provide further opportunities for innovation.

\section{Research themes}

The iBUILD research programme is structured around three major research activities to stimulate innovative thinking around infrastructure business models:.

The business of interdependence. Identifying how to 'unlock' the technical and market opportunities, whilst managing the associated risks that emerge from the increased interdependence of modern infrastructure systems.

Re-thinking value. Challenging and enhancing current approaches to assessing infrastructure value to enable leveraging of economic, social, environmental, aesthetic and other dimensions of 
value.

Issues of scale in local delivery. Reconciling the local scale at which infrastructure services are provided with regional, national and global scale priorities around strategic planning, financing, procurement and operation.

New business models that emerge from these activities will be stress tested, in partnership with stakeholders, on a series of case studies to provide crucial evidence of their practicality and benefits.

\section{4 year programme}

Following an announcement by Lord Deighton, Commercial Secretary to the Treasury, the research programme began in Autumn 2013 and will last for 4 years. The Centre comprises a multidisciplinary team that includes civil engineers, economists and social scientists from Newcastle, Leeds and Birmingham Universities and is led by Richard Dawson from Newcastle University.

\section{For further information, or to join the stakeholder group, please contact}

Professor Richard Dawson

Tel: +44 (0) 1912086618

Email: richard.dawson@ncl.ac.uk

Website: $\underline{w w w . i b u i l d . a c . u k}$

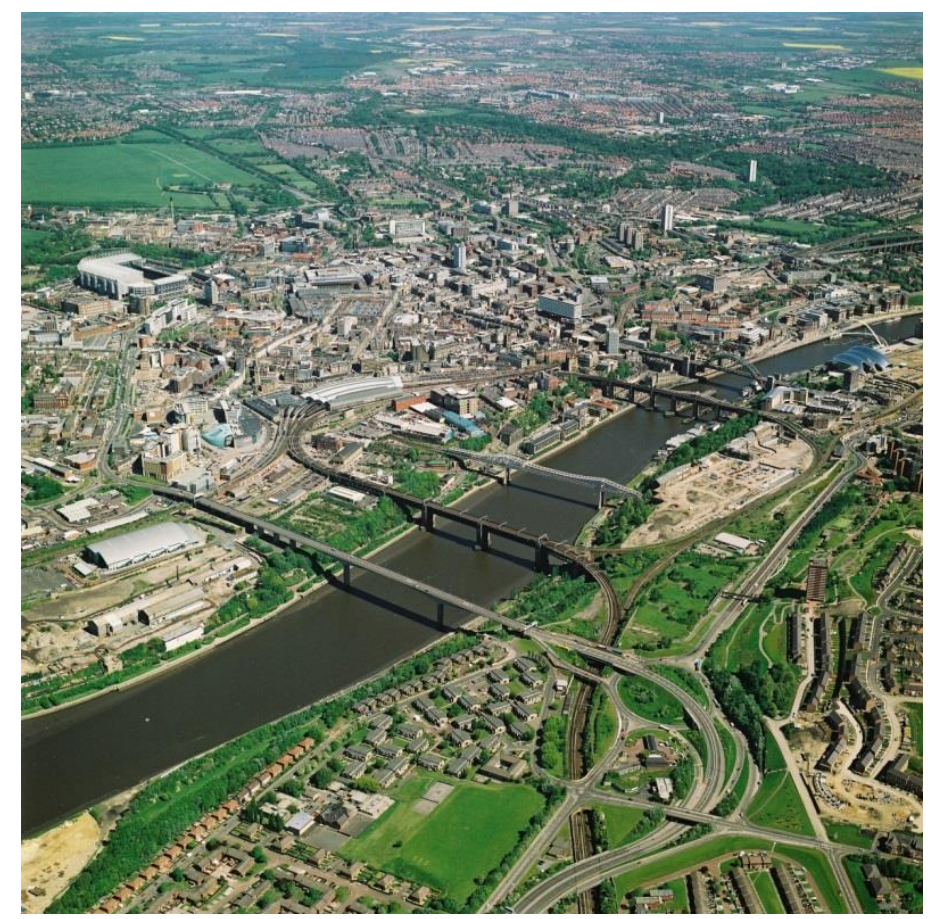

iBUILD aims to develop and demonstrate a suite of infrastructure business models for local and urban infrastructure.

\footnotetext{
i HM Treasury (2011) Review of Private Finance Initiative. Treasury Select Committee Review, London, UK.

ii Infrastructure UK (2011) National Infrastructure Plan. HM Treasury, London, UK.

iii McKinsey Global Institute (2011) Urban World: Mapping the economic power of cities. McKinsey, USA

iv IPPR (2011) Northern Prosperity is National Prosperity. Institute for Public Policy Research

${ }^{\vee}$ DCLG (2011) Unlocking Growth in Cities. Department for Communities and Local Government.

vi Strickland T (2013) The financialisation of urban development: Tax Increment Financing in Newcastle upon Tyne, Local Economy, 28(4):384-398.
} 